\title{
Deep Approaches to Learning in Improving Reading Skills: A Case Study from Yunnan Agricultural University*
}

\author{
Liping Chen \\ School of Foreign Languages, Yunnan Agricultural University, Yunnan Province, Kunming 650201, China \\ Email: annaclp@sina.com
}

Jaswinder K. Dhillon (Corresponding author)

School of Education, University of Wolverhampton, Gorway Road, Walsall WS1 3BD, UK

Email: J.K.Dhillon@wlv.ac.uk

\begin{abstract}
Reading is an essential method of gaining knowledge and information for a variety of purposes including social, educational, cultural and vocational/professional. For many people, reading also involves translating information into their own language and thus adds a further dimension to the complexities of understanding the information that they read. This is the case for many university students who need to develop proficiency in reading in English for their degree qualifications. This paper reports on an a case study at Yunnan Agricultural University (YAU) that explored ways to change students' approach to learning by encouraging them to adopt a deep approach to learning in developing their reading skills in English. After a four-month training programme, a comparison of student test scores, showed that the 3P model of teaching and learning is suitable for developing the reading skills of students who are non-English majors, helping them to adopt a deep approach to learning in their reading. Through taking a deep approach to learning and changing attitudes and methods in teaching reading lecturers can effectively foster the students' reading skills and improve their achievement.
\end{abstract}

Index Terms - deep approaches to learning, the 3P model, reading skills

\section{INTRODUCTION}

Reading is an essential skill for English as foreign language (EFL) students; and for many, reading is the most important skill to master. With strengthened reading skills, EFL readers will make greater progress and attain greater development in all academic areas (Anderson, 2009). The main purpose for reading is to comprehend the ideas in material. Reading involves at least three types of skills - decoding comprehension, and reading strategies (Deng Yumei, 2009). At Yunnan Agricultural University (YAU), as in other colleges and universities, there are cases where students can read the words, sentences and passages but face much difficulty in their comprehension of the main ideas. This is because of the students' lack of ability of comprehension of reading material. The issue of how to enhance teaching efficiency and develop students' reading comprehension ability is thus a fundamental question for English language teaching.

At YAU almost all students who are non-English majors are required to learn English for four semesters. In each semester, students use one set of textbooks and much of the time of a semester's classes should be spent on reading. In each set of the textbooks offered, there are 'Integrated Course', 'Reading Course', 'Fasting Reading', and 'Listening and Speaking Course'. At YAU the new edition of textbooks in the series, New Century College English, which are meant to develop the students' abilities in listening, speaking, reading and writing are used.

But because of various reasons, students' ability in English reading comprehension is not very satisfactory. Students' reading level does not measure up to the reading ability which is essentially needed in the reading process. How to help students improve their reading ability has thus become a prevalent problem for college English teachers.

According to Clark (1987), reading skills, include scanning, skimming, reading for thorough comprehension and critical reading while language skills refer to vocabulary, structure and discourse. Bias towards or against either reading will not only enable students to gain access to information, but also to proficient skills, which are the two sets of skills that determine the very goals of the teaching of reading in Chinese higher education.

There are various factors that affect students' reading comprehension.

"The method used is mainly structure-based, the focus of teaching is on language form and the class is teacher-centered. The common teaching pattern is reading, questioning, explanation and grammar exercises. Students depend too much on the teacher and lack a sense of responsibility for their own learning."(Shu Baimei, 1996)

\footnotetext{
* The research was supported by Yunnan Education Science "Eleven Five” Layout project (GY08024)
} 
Non-English majors' reading teachers pay little attention to cultivating students' ability to comprehend the whole text at discourse level. Instead, much attention is given to linguistic knowledge. Frequent interference from teacher's overemphasis on linguistic competence in class actually prevents students' improvement in reading comprehension. In this way, any unfamiliar words or complicated structures would be the barrier to the success in understanding the passage. Moreover, sometimes even if they understand the words and grammar very well, still they have much difficulty in understanding the text deeply. Therefore, all these problems call for developing students' discourse competence in the college English reading classroom. This study concentrates on the function of deep and surface approaches to learning and how they affect students' reading comprehension. It used the following research questions as a framework for the investigation:

1. What approaches to learning do the students take in their language learning?

2. How can the teachers encourage the students to adopt deep approaches to learning in reading?

3. How effective are deep approaches to learning in improving reading comprehension?

This paper reports the findings of an experiment where teachers introduced strategies to encourage the students to adopt deep approaches to learning in reading at YAU.

\section{DeEP APPRoAChes to LEARNing AND THE 3P Model of LEARNing AND TEACHING}

Deep and surface approaches to learning are the ways of learning a particular task; it is not the characteristics of students. Biggs (2003) states "the surface approach arises from an intention to get the task out of the way with minimum trouble while appearing to meet the course requirements". (p.14). Surface approaches to learning describe an intention to complete the learning task with little personal engagement, seeing the work as an unwelcome external imposition. This intention is often associated with routine and unreflective memorization and procedural problem solving, with restricted conceptual understanding being an inevitable outcome (Entwistle \& Ramsden, 1983; Trigwell \& Prosser, 1991; Marton and Salio, 1997; Entwistle, McCune, \& Walker, 2001).

"The deep approach arises from a felt need to engage the task appropriately and meaningfully, so the student tries to use the most appropriate cognitive activities for handing it." (Biggs, 2003, p.16). Deep approaches to learning, in contrast to surface approaches, lead from an intention to understand, to active conceptual analysis and, if carried out thoroughly, generally result in a deep level of understanding. This approach is related to high quality learning outcomes (Entwistle \& Ramsden, 1983; Trigwell \& Prosser, 1991).

So good teaching should try to encourage the students to take a deep approach and discourage the surface. Ramsden (2003) says "the way in which anyone goes about learning is a relation between the person and the material being learned" (p.14). The approach can be thought of as a qualitative aspect of learning and this is excellently described by Ramsden (2003) 'it is about how people experience and organize the subject matter...it is about 'what' and 'how' they learn, rather than 'how much' they remember." (p.14). Lizzo et al. (2002) suggest that perceptions of heavy workload and inappropriate assessment influence students towards surface approaches to study, but a good teaching environment influences students towards deep approaches to studying. Kember and Leung (2006) suggest that careful attention to the teaching and learning environment can spur students to work hard without feeling overly stressed. Cano (2007) states students who use a surface learning are trying to avoid failure with the minimum amount of effort and involvement. Deep and surface learning are motivated by different factors and would be expected to move in a consistent pattern in relationship to each other. Draper (2009) develops more of the idea by concluding that shadow learners understand the material correctly, but simply do not have the connections between concepts that deep learner do.

Students who use a deep approach to learning can transfer the learned concepts to a variety of situations by that means creating a denser matrix of connections within their knowledge and understanding. Research has shown that shifting from traditional instructor-dominated pedagogy to a learner-cantered approach leads to deeper levels of understanding and meaning for students (Lave\& Wegner, 1991; Tagg, 2003; Sim 2006).

But how to encourage the readers to use deep learning in their reading is the main problem for the teachers; the $3 p$ model of learning and teaching may be a good way to solve the problem.

The 3P model of learning and teaching

Biggs' model of constructive alignment, reproduced below, posits that a good teaching system aligns all aspects of teaching to support appropriate learning.

Presage Process

Product

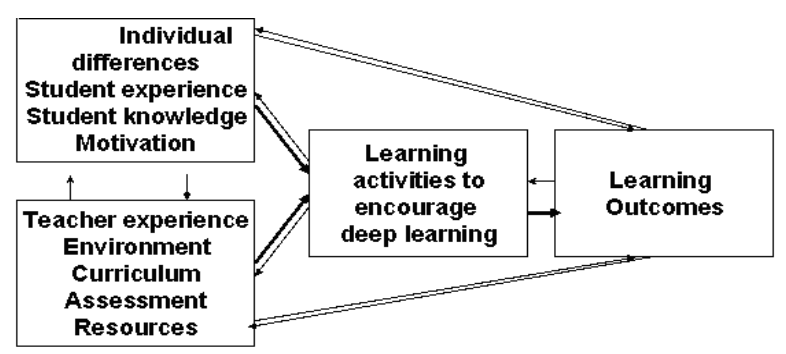

(Biggs, 2003, p19) 
presage: before learning takes place

process: during learning, learning focused activities; students' approach to learning

product: learning outcomes, which depend on the focus of the teaching

The 3P model describes teaching as a balanced system; all components need to be aligned to each other, except for the students-based factor and teachers factors, the most important components include:

1. The curriculum that we teach.

2. The teaching methods that we use.

3. The assessment procedures that we use.

4. The climate that we create in our teaching.

5. The institutional climates, the rules and procedures we have to follow.

This study used Biggs' ideas and assumed that when teachers plan a programme of appropriate learning activities, they should consider these theories in order to teach effectively.

\section{RESEARCH DESIGN}

\section{A. Methodologies}

A strategy from qualitative approaches that is pertinent to this research is the case study which involves an in-depth exploration of an event, program, an activity or process (Creswell ,2003; Dencombe ,2007; Walliman ,2001; Cohen et al ,2000).

This study involved investigation of students applying deep approaches to learning to improve their reading ability at YAU. Two tests, questionnaires, observations, interviews with the participants and students reflective dairies were used to gather the data to provide an in-depth knowledge of the case (Politt et al, 1999)

This case study is also comparative in nature involving some form of comparison between the students who were adopting deep approaches to learning in reading and the students who read in traditional ways. So in the interviews students were asked questions like "how do you feel about adopting the deep approaches to learning in reading? How does it enhance your reading ability?"

From the research, a general picture of encouraging the students in other universities in China may be drawn out as Nisbet and Watt (1984) note that case study, as a specific instance, "is frequently designed to illustrate a more, general principle." (p.72). Tellis (1997) highlights that case studies have been used to develop critical thinking. This is also central component of the topic being researched.

\section{B. Research Process}

\section{Objectives}

Throughout the training, observations are focused on the effects of the training on the subjects: whether the deep approaches to learning in reading is beneficial to improving students' English reading ability.

\section{Subjects of experiment}

The subjects participating in the experiment in this study all come from non-English major classes in YAU. Subjects are sophomore from two parallel classes. The first class consists of 64 students ( 36 boys and 28 girls), while the other contains 64 students (30 boys and 34 girls). Since they are non-English majors on their fourth term, few of them have received systematic training on English reading. Both Class 4 and Class 24 are classes formed by agronomy, biotechnology, plant protection, animal and plant quarantine, horticulture majors. Through pre-test of English reading level we found students almost at the same reading level.

\section{Procedures}

The experiment extends from March of 2011 to June of 2011 .During these four months; both classes receive two-periods of teaching on reading every week.

\section{Stages of the Experiment}

The experiment can be divided into four stages as follows:

1) Before training, the first questionnaire is used to find out the students' learning approaches. The second questionnaire is made up of twenty questions. Another questionnaire is five ways to become a deeper learner.

2) Found out the major problems at text level in students' reading that are influenced by traditional teaching method.

3) The purpose of the pre-test was to testify whether the English proficiency of the two classes at the beginning of the academic year was about at the same level.

4) According to these major problems and learning style, experimental class is given courses focusing on the deep approaches to learning with theory of 3P model in reading of the text. While at the same time, control class is still taught according to the traditional way of reading teaching from the course book.

5) After training, a post-test is used to check whether there are differences between these two groups of students, when adopting deep approaches to learning in reading can understand the meaning of the text better.

\section{Analysis And Discussion of Data}

The data will be organised under the heading of each research question, and draw together all relevant data for the 
exact issue of concern and preserve the coherence of material (Cohen et al ,2007; Wellington ,2000). The quantitative and qualitative data will be analyzed from the aspect of various attributes of students learning approaches, ways to deep approaches to learning, and the reading skills in teaching reading, the results of pre-test and post-test.

\section{What approaches to learning do the students take in their language learning?}

\section{A. Analysis of the Questionnaire}

\section{Analysis of Approaches to Studying Questionnaires}

Before experiment training, the first questionnaire was used to find out the students learning approaches in their English learning. Data from the Approaches to Studying Questionnaires revealed that students' approach in their learning in different ways.

SCALE SCORE
\begin{tabular}{|l|l|l|}
\hline scale & Experiment Class & Control Class \\
\hline (A) Achieving & 12.85 & 12.71 \\
\hline (B)Reproduction & 15.65 & 15.55 \\
\hline (C) Meaning & 12.73 & 12.51 \\
\hline
\end{tabular}

This is out of 24 on achieving orientation, the number of A indicates competitiveness, well organised study methods and hope for success. Students who score high on this scale are orientated towards doing well, whatever this involves.

This is out of 24 on reproducing orientation; the number of B indicates a surface approach to learning. Students who score high on this scale to memorise and reproduce subject matter and have desire to accumulate knowledge. They tend to keep narrowly to syllabus as laid down in course descriptions and not to follow up interest of their own.

This is a score out of 24 on meaning orientation; the number of $\mathrm{C}$ indicates a deep approach to learning: an intention to make sense of the subject, an interest in the subject itself, and a desire to learn. Students who score high on this scale follow up their interest even if these are outside those parts of the course which are assessed.

The students, who score a little higher in B, show that many students adopt a surface approach to studying. This is common phenomena in YAU, especially in west part of China. Most students like to be told precisely what to do in their work; only few of them definitely agree that they usually set out to understand thoroughly the meaning of what they are asked to read. When the students got their total number I explained the meaning of the letter A, B, C, and introduce the surface and deep approaches to learning. They are asked not to pay attention to the learning approach used at that time, but from then on, try to change the way they study, adopting a deep approach to learning in their language study, especially in text reading.

\section{Analysis of the questionnaires on students' reading skills}

\section{Results of the questionnaire}

In order to obtain respondents' accurate replies to the same questions; a questionnaire, which was modified from Chen Jin (2005), consisted of 20 questions. Each of them was followed by 4 choices marked A, B, C and D. The respondents were required to choose only one answer for each question within the same frame-work. 64 copies of the questionnaire were distributed among the second-year students, and 64 valid ones were collected. The subjects were asked to express their opinions openly and honestly. The results of the experiment were computed with the help of the students.

\section{Findings}

After the analysis of the questionnaire, a series of practical problems arising in carrying out the teaching programs to the students couldn't be ignored.

1) Effects of Linguistic-level Problems on Reading

2) Deeply-rooted language ideology

3) Effects of meta-cognitive problems on reading

4) Text linguistic-problems in the Teaching of Reading from the $3 p$ model of learning and teaching

5) Pragmatic-level Problems in Reading Instruction

6) Lack of Cultural Knowledge and Affective Problems in Reading

How can the teachers encourage the students to adopt deep approaches to learning in reading?

3. Analysis of questionnaires on ways to become a deeper learner

The result of the third questionnaire is as follow.

\begin{tabular}{|l|l|l|l|}
\hline You can become a deeper learner by & Already do & Can do & Will do \\
\hline 1. Asking yourself questions & 15 & 18 & 31 \\
\hline 2.Making comparisons & 18 & 20 & 26 \\
\hline 3.representing new ideas as many ways as possible & 10 & 18 & 36 \\
\hline 4.Creating your own summaries & 11 & 19 & 34 \\
\hline 5. Creating mind maps & 5 & 15 & 44 \\
\hline
\end{tabular}

The table reveals that most students want to become a deep learner. Through the questionnaire the students will try to use the ways in their language learning, especially in reading. This demonstrates that most students want to change their learning habit, improve learning outcome. The students who have the belief in their study can get ready to receive the 
experiment.

\section{B. Practice of Teaching}

Experimental class is given courses as following by focusing on the $3 p$ model on meaning construction in reading. Take Unit 5 Text A: Fame from New Century College English, Book IV (Qing xiouBai \& Chui Lin, 2008) as an example. Our purpose is to see how the Presage, process, product of the 3 p model interact with each other in the constructing learning.

\section{Pre-reading Activities}

Student-student interaction in the large -class setting, students like learning from peers, according to Biggs(2003), peer interaction leads to valuable outcome of its own: elaboration of knowledge, awareness of standards of knowing, reflection leading to meta-cognitive awareness and various word knowledge, syntactic knowledge, background knowledge, cognitive schema, , context, structure, affective factors---interests and motivation, prediction, scanning, pair work, group work.

The pre-reading activities are planned for two purposes. On one hand, it is to interest and motivate learners. According to Goodman (1967), reading is a complex process by which a reader reconstructs, to some degree, a message encoded by a writer in a graphic language. Widdowson (1983) stated the psycholinguistic view of reading assumes reading to be an active process, in which the reader is an active information processor.

During the preparation for the text, I asked the students to activate their previous knowledge to construct their personal understanding to the text. For example; when they will read new words and the text by themselves, they may think about qualities of successful people. They will predict what the author will say according the title, words, and notes.

For background knowledge, they can surf on line and find some famous persons in the world. The students can put all these together, and construct their own meaning of the discourse by the recognition of the text type, the text division, the text outline, etc. The teacher should set some tasks which can activate their previous knowledge and make students actively involved in the task.

While-reading Activities

As Widdowson (1979) states it, reading is a problem-solving process. In our understanding of the text, we are more concerned with the discourse analysis. In doing so we generally ask our students to bear in mind such questions as "What is the text actually about?" "Is the author for or against..."etc. and to seek for such specific information of the text.

Discourse analysis is carried out on two aspects: how an idea is developed and how one idea leads to another (introduction, development and conclusion). No matter what method we use we use it "to help students develop an awareness of conceptual presuppositions that native-speaker writers and readers apply to the organization of a text" (Clark et al, 1987, p.242).

It is the right time for the teacher to push the students a step further. The teacher should encourage them to form their own evaluative judgment about what they have read. We find it very helpful for cultivating in the students a habit of evaluating in reading as well as for training students' ability for oral practice. We generally carry out this process by asking students to read the text a third time and then answer questions.

Usually, group discussions are held before the students answer the questions.

Question 1 (asked by the teacher): what ironic phenomenon does the author point out? (Two minutes later)

Question 2: what type the text is? Give your reasons.

Student H: this text is descriptive.

Student I: this text is argumentative.

Student J: this text is expositive.

Students can give answers, but they can't give reasons. The teacher then should make these differences clear.

Question 3: since we have learned the text type, can you analyze this text?

Step 1: We ask students to do this work in group and each group can present their ideas in discussion.

Student K: the first paragraph is the first part, which is the argument for the whole passage: Chasing fame often leads to self-destruction.

Student L: from Para. 2 to Para 5 is the main body of the text....

Student M: the last paragraph is the conclusion of the text. It is better to take a critical attitude towards fame.

Step 2: After students have finished their work, we emphasize the cognitive schema of the text- the introduction, the body and the conclusion and how to find them.

Step 3: the teacher asks students to outline the text in their own words.

\section{Post-reading Activities}

The last dimension of activities of this approach is so developed as to check comprehension, to consolidate language skills and to enable further reading. The textbooks we use generally contain comprehension check-up exercises. Besides these we also assign students outline and summary writing and outside reading tasks.

We believe that the amount of reading will eventually help improve reading proficiency and skills. The amount of outside reading is usually double that in the reading class. For each reading task we give students three types of questions (pre-reading, while-reading and post-reading) to guide their reading and check their comprehension. 


\section{How effective are deep approaches to learning in improving reading comprehension?}

\section{The Qualitative Result of Interview}

For the purpose of interview in this study is to further understand the effectiveness of training in the experimental class, all the interviewees are the students involved in training. 6 students who are randomly chosen in the experimental class attend the face-to-face interview. The face-to-face interviews are done to the 6 participants in the experimental class to have further understanding of the influence of the training program. The 6 participants are chosen at random. The participants are informed that the interview is just to collect some information about the training. It is emphasized that there is no right or wrong answer to the questions and what the interviewer wants to know is "what do you do" and "what do you think".

Questions of interview with participants:

1). In your opinion, what is the deep approaches to learning?

2). In the training, what impressed you the most in the training program?

3). Do you think, the deep approaches to learning is helpful to in improving reading comprehension?

Six participants which are chosen at random attended the interview and answered the above three questions. The interview is in Chinese so that participants have no difficulty in expressing themselves clearly. We translated them into English. The main contents of interview are as follows:

\section{Answers of question 1:}

A. The deep approaches to learning, according to teacher's explanation, are a kind of approach to learning but not forced by teachers or some other people. For me, the deep approach to learning is to try to learn something by reading widely with previous relevant knowledge.

B. The deep approaches to learning, I think, we can have chance to take responsibility for our own learning.

C. When we try to become deeper learners, we try to become interested in reading as much as possible.

D. The deep approaches to learning? I don't know it very well. Perhaps, learn something deeply? Sorry, I am not sure.

E. We may consider the deep approaches to learning as a higher-level learning, the process as the machine is working. It is driven by our zeal and my teacher's encouragement. It is my understanding.

F. My English teacher mentioned "The deep approaches to learning" from time to time in class. Err... I think it is a trial to learn by ourselves wonderfully.

\section{Answer for question 2:}

A. In training, the teacher encouraged us to do something by ourselves, changing the learning attitude and method. For example, to evaluate what we have done by ourselves or partner. It is really new experience for me. Before, we always waited for the answer or marks from teacher and took it as evaluation and result for granted. We believe it and we rarely try to value ourselves. This makes me more confident and successful.

B. The teacher gave us the chance to read English text differently which involve the group work. But I am not used to this. I am not sure whether I can do it well or not.

C. In the training, the teacher always asked us to read text and explain or reflect. But I am still not so familiar with how to reflect. I am not sure I will do it well or not.

D. In the training, I can have the opportunity to set a goal for me and form my own ideas. I am so happy to actively relate new information to previous knowledge. I like to study with others, But, frankly, I don't know whether my way and result of evaluation are proper or not.

E. I feel exciting when I read English. The classroom climate we create is excellent. I had planned my language learning many times before, but I failed to follow it. This time, it is a group work.

F. The teacher often suggested us to read using several reading skills. It is not the same as before. We can only sit in classroom and listen to teacher's talking before. Now we are busy in class. In fact, I prefer the way the teacher used before, since I can understand her talking without doing any thing by myself.

\section{Answer for question 3:}

A. Maybe. I am not sure. But it is really a new experience for me.

B. I think so. Now when I read an article, I will try to summarize the readings and visualizing the key ideas, but not memorize words or phrases for a day or two. I can understand the text better than before.

C. Err ... language learning is still a headache for me, especially reading.

D. It makes me clear that what I want to get from language reading class. But I am not sure it will be helpful to my language learning. It may be a long process. I hope it will be helpful. We have learned English for a long time, but not effectively.

E. I think it is effective in some respect. Now we are exciting when we are learning English. But we are not certain whether this excitement will last long or not.

F. I don't think there is much difference.

From the answers of question 1 in the interview, we see that most of participants involved in interview have basic understanding of the deep approaches to learning even if they do not understand the connotation of the deep approaches to learning quite deeply. But we also find that one of these participants are not so clear with the concept of the deep approaches to learning and take it as learn deeply.

For most of the participants, the most impressive elements in the training program are group work, cooperative study, 
self assessment and peer assessment. They intend to accept new way of learning and try to adopt the deep approaches to learning with the assistance of teachers' encouragement and instruction. We also find that they do not mention the strategies of the deep approaches to learning directly in the interview. Participants consider activities of planning and self-evaluation as new experience to them. They dare not use new ways frequently since they are not sure whether they are practical or not. A sense of insecurity stemmed from unfamiliarity may decrease the use of the deep approaches to learning being taught. In learning and using new learn style, learners may feel unfamiliar and their security in learning is challenged. They will be not sure about their comprehension of reading by using new learn style or to be skeptical about the efficiency of their efforts. To remove their hesitation, the teacher's encouragement will be helpful to promote them to attempt to use new strategies more frequently during the process of the deep approaches to learning. To most of participants, the deep approaches to learning, in their opinions, is helpful to their language reading in some respects. But there is still an obstacle for them to adopt the new learning style smoothly. They are not sure this way of learning will be helpful for learning for a long time or not, since they are wondering whether they will continue to learn by this way when it is not fresh to them. At the same time, few participants do not think there are obvious differences between the influences made by learning methods they used before and the deep approaches to learning.

From the interview, we find that on one hand, most of the learners have basic understanding of the deep approaches to learning and are apt to adopt the deep approaches to learning after training. On the other hand, they are not sure whether the deep approaches to learning will be helpful and effective to their learning constantly or not. It is the usual action and feedback when one is facing new way or unfamiliar things. They need more encouragement and successful cases which may raise their confidence.

\section{Data Obtained from Pre-test and Post-test}

Both of the classes are given 2 English reading proficiency tests, which are pre-test and the post-test. The purpose of the pre-test was to testify whether the English proficiency of the two classes at the beginning of the academic year was about at the same level. After the pre-test, the first class is chosen to be the experimental class (EC) and the second class the controlled class (CC). By the end of training, the subjects had taken the same post-test of reading .The teacher, the syllabus; the book and the teaching schedule are the same for both classes during the whole process.

A pre-test and a post-test of reading comprehension are conducted to the 128 participants in this research. Each test paper contains two articles with 10 reading comprehension multiple choices. All the articles are all adapted from the test paper of College English CET-4 randomly. The full mark of a test paper is 100. We use these tests to acquire the participants' marks and levels of reading comprehension performance.

The raw data of pre-test and post-test are keyed into computer and analyzed by SPSS V.10.0. The descriptive statistics of the reading performance for the experimental class and controlled class are reported in following table.

TABLE 1

THE DESCRIPTIVE STATISTICS OF READING TESTS

\begin{tabular}{|c|c|c|c|c|c|c|}
\hline \multicolumn{4}{|l|}{$\mathrm{EC}$} & \multicolumn{3}{|c|}{$\mathrm{CC}$} \\
\hline & $\mathrm{N}$ & Mean & SD & $\mathrm{N}$ & Mean & SD \\
\hline Pre-test & 64 & 46.82 & 10.64 & 64 & 45.56 & 11.23 \\
\hline Post-test & 64 & 61.5105 & 11.6295 & 64 & 53.8533 & 16.4049 \\
\hline
\end{tabular}

Note: $\mathrm{EC}=$ experimental class, $\mathrm{CC}=$ controlled class

In the pre-test, the mean of EC is 46.82 and standard deviation 10.64. In the post-test the mean of EC is 61.5105 and standard deviation 11.629. Then the independent sample t-test shows that $Z=6.9118>2.58(\alpha=0.01)$. It is concluded that the reading performance of EC is improved significantly after training compared with their performance in pre-test. As for the CC, in pre-test, its mean is 45.56 and standard deviation 11.23 , while in the post-test; the mean is 53.8533 and standard deviation 16.4049. The independent sample t-test shows that $\mathrm{Z}=3.804>2.58$. The result is also significant but not as great as the EC's performance.

This indicates that the difference in reading comprehension ability between the two classes is significant. Table 1 demonstrates that students from Experimental class achieved better results in reading comprehension after being exposed to the teaching with the $3 \mathrm{p}$ model than those from Control class who have a little improvement in their reading.

According to the result of comparison of the two classes' test at the end of the training, it can be inferred that it is the different way of teaching that results in the dissimilarity among the students' reading ability. Experimental class benefits from the teaching on the $3 p$ model by encouraging students adopt the deep approach to learning on reading. Therefore, the hypothesis has been testified: teaching and training of $3 p$ model on reading does contribute to the improvement of students' English reading ability.

To sum up, all those studies and experiments indicate the necessity, feasibility and practicality of the instruction on the $3 \mathrm{p}$ model on meaning construction in reading. In the surface approach the students may try to memories facts or focus on the meeting the assessments criteria in order to reproduce them in the examinations and pass the course (surface motive). In the deep approach the students will engage with the task in order to understand what the author is saying, thus the aiming to understanding the further meaning (Dickinson, 2002, Biggs, 2003, Marton \& Salio, 1997). The students employing a deep approach might integrate the known knowledge and the practical uses with the intention to understand make sense of the text (deep motive). When the students deepen their understanding of the meaning of the 
text, they try to establish a new semantic network for those types of passages, reading skills and strategies. They need to change the way they memorize and store these information in their long- term memory. So it is obvious that after a long time they can get higher mark in the test.

\title{
E. Sample of Observation
}

\author{
22nd March 2011 \\ After two week's training, I found the atmosphere of the class changed a lot, most students like to speak in or out of \\ class, especially the students who seldom answer questions in class, now they can answer questions confidently and \\ successfully. The attitude towards learning for the students also change a lot, those who often late for the class will \\ come on time, they hope to listen to the other students presentation, they want to talk in the class in English. Almost all \\ the students can fulfill the assignment I want them to do.
}

\section{F. One of Students Reflective Diaries}

\section{G. Discussion}

Both deep and surface approaches to learning are not personality traits or fixed learning styles, students can adopt an approach which is based on their perception of the task. So It is one of key way s in which teachers can influence the students approach is to use the learning intentions and motives of students as a "driver" for change and better engagement.

The learners can move from the different approaches and for some of the students personal life or knowledge, they highlighted their perceptions of deep or surface learning during their reading study.

Marton and Säljö (1997) asked students to recount how they had been handling their learning task and how it appeared to them. Besides the questions about what they remembered of the text its content, students were also asked questions designed to discover how they tackled this reading task. The results show an astonishingly simple picture: the students who did not get 'the point' (i.e. understand the text as a whole) failed to do so, simply because they were not looking for it. The main difference in the process of learning concerned whether the students focused on the text itself or on what the text is about: the author's intention, the main point, the conclusions to be drawn. In the latter case the text is not considered as an aim in itself, but rather as a means of grasping something which is beyond or underlying it. It can be concluded that there was a very close relationship between process and outcome. The depth of processing was related to the quality of outcome in learning (Marton \& Säljö, 1997).

Inappropriate assessment procedures encourage surface approaches; yet varying the assessment questions may not be enough to evoke fully deep approaches (Ramsden, 1997).

Entwistle (2001) also found that students who reported themselves as adopting surface approaches to learning preferred teaching and assessment procedures which supported that approach, whereas students reporting deep approaches preferred courses which were intellectually challenging and assessment procedures which allowed them to demonstrate their understanding. A direct consequence of this effect is that the ratings which students make of their lecturers will depend on the extent to which the lecturer's style fits what individual students prefer (Entwistle \& Tait, 1995).

Therefore, in my further teaching, I'm going to apply more flexible, effective and updating methods of teaching and maximize the chances that students will engage the full understand of the text needed to achieve the desired outcomes, e.g. problem-solving activities in small group, using pictures to make up stories, teacher-directed activities, self-directed activities, student-student interaction, group-discussion, peering-teaching, etc, which motivate my students positively. Change the intention to complete task requirements which are attached to the examination and make students be in intrinsic motivation.

When the students have the intrinsic motivation, they will have a positive attitude and confidence, which can enhance study value.

To encourage deep learning strategies, teachers can consider how to make creative to make our teaching methods and approaches to create opportunities for deep learning. Methods such as using learning lists, and getting our students to read a variety of texts on the theme so that they have greater number of opportunities to experience relevant items perhaps even in different contexts can help encourage deep learning.

\section{CONCLUSION}

\section{A. Conclusion}


The research has probed into the English reading in YAU non-English majors. Based on the surveys on the current situation of reading in the college as well as problems in students' reading, we can see the necessity of teaching on $3 p$ model on reading encouraging adopting the deep approach to learning; based on the result of the experiment, we also can see the feasibility of such way of teaching in improving students reading ability.

Through experimental teaching, students can become a deeper learner by $3 \mathrm{p}$ model. They can be expected to recognize it is important to be conscious of constructing the meaning of the text by themselves when they read in English.

From the above analyses and discussion, a conclusion can be drawn that it is very useful and helpful for the students to adopt deep learning in English reading. They can not only change the attitude to the study in reading but also improve the abilities of their language learning.

It can also be concluded that the teacher use deep learning which leads students to build confidence, most students I am sure they can figure out what they confused and like to read English. Deep learning brings happiness, a sense of satisfaction and great motivation in their English learning.

In deep learning, the students are encouraged to become independent learners, making something their own, to take responsibility and create a personal conceptual framework of knowledge and understanding (Entwistle, 1988).

The deep approach to learning in reading is necessary for college English teaching in China. First of all, most college students are adult language learners and they do not have the same capacity for language learning as pre-critical period learners do. As we all know when advanced proficiency is important for adult learners, something will be needed to compensate for the incapability for language learning. So the deep approaches to learning in reading are the suitable choice to compensate for the incapacity of college students in reading. Secondly, the deep approaches to learning in reading have its rise in popularity in YAU and the other English teachers will prefer this kind of instruction. The present study in this paper also provides a strong evidence that the deep approaches to learning in college English reading class works more efficiently than traditional instruction in improving students' language ability. Therefore the deep approaches to learning are suitable for college English teaching in YAU.

\section{B. Limitations}

The study designs a refined program with the students using the deep approaches to foster learner reading skills based on the previous learning approaches research. The result shows that it is effective in some respects, although the experiment in some aspects is not as successful as we expected. It is concluded that the students who adopt the deep approaches in their intensive or extensive reading in or out of classroom is helpful to foster learner reading ability. This research may raise both educationists and researchers' interest of this field to struggle for an improved research program for both teachers and learners. Due to various reasons, conclusions drawn from the study are tentative in nature, for the study itself has some limitations.

First, the experimental expand is relatively short. As we discussed before, the experiment of deep approaches in reading is a time-consuming process. Four months with 32 periods of 50-minute classes is relatively short for this research. It affects the significance of changing learning approaches to some extent. As the experimental program involves several instruments, the improvement of students' reading ability is broad and complex issue .There is many components interweave with one another. Besides, the study was conducted in one university. A few studies have been done on the application of non-verbal communication in College English reading courses; therefore, there is much room to be studied in this field. Based on the study, we are supposed to be explored in more details in further studies.

Secondly, the validity of questionnaire designed for the study is still to be enhanced. .The participants involved in this research are all students majoring in some specialties. Some more participants in other majors should be involved in experiment to make the result more convinced. Absence of more scientific measurement remains an unsolved problem in present researches. Attentions should be paid to this domain in further studies.

Thirdly, only one teacher is involved in the pre-training and no sufficient time is offered for her to think over the knowledge of students other abilities, learner autonomy and metacgonitive strategies, and skills of training etc. The instruments adopted in the experiment may not suit to all foreign language learners. New approaches need to be found and used, and investigations on individual differences in the experiment program are also needed in further studies. Many more researches in this field should be done from different perspectives.

Although theories of the deep approaches to foster their reading skills are important they are just one of the many devices and issues in reading and cannot solve all the problems in reading. Due to the limitations of our knowledge, this paper leaves room for more research. In respect of future study, more accurate empirical research should be pursued.

\section{REFERENCES}

[1] Anderson N. J.(2009). Exploring second language reading: issues and strategies. Beijing: Foreign language teaching and research Press and Cengage Learning, p1.

[2] Biggs, J. (2003). Teaching for quality learning at University. Second edition. London: The Society for Research into Higher Education \& Open University Press. pp57-73, p14, p16, p95.

[3] Biggs, J. (1987). Students Approaches to learning and Studying. Hawthorn, Vic: Australian Council for Educational Research.

[4] Boud , D. (1988). Developing Student Autonomy in Learning. London: Kogan Page. 
[5] Cano, F. (2007). Approaches to learning and study orchestration in high school students. European Journal of Psychology of Education, 22(2), 131-150.

[6] Carrell, P. L., Davine \& D. E. Eskey. (1989). Interactive Approach to second Language Reading. Cambridge: Cambridge University Press, p1, p220.

[7] Carrell, P. L. and Eisterhold, J. C. (1983). Schema Theory and ESL Reading Pedagogy. In Carrell et al (eds.) Interactive Approaches to Second Language Reading: PP67- 82.

[8] Chen Jin (2005). A social constructivist model of meaning construction in ESL reading. Liaoning normal university graduate department.

[9] Chionel NE, Can Der Veen RGW, Wildemeersch D \& Jarvis, P. (2003). The validity and reliability of focus groups as a research method in Adult Education. International Journal of Lifelong Education. Vol.22. No.5. pp495-517. http://www.informaworld. com 04/03/11.

[10] Clark, Mark, A., \& Silberstein, Sandra. (1987). Toward a realization of psycholinguistic principles for the ESL reading class. Language learning, 27(1). (pp. 136-137).

[11] Cohen, L., Manson, L. and Morrison, K. (2007). Research Methods in Education (6 ${ }^{\text {th }}$ Ed).Abingdon, Oxen: Routledge, p37, p260.

[12] Creswell, J W. (2003). Research Design: qualitative, quantitative and mixed methods approaches (2 ${ }^{\text {nd }}$ Ed). London: Saga Publication.

[13] Denscombe, M. (2007). The Good Research Quide: for small scale social research project ( ${ }^{\text {rd }}$ Ed). Maidenhead: Open University Press.

[14] Deng Yumei, (2009). A study of the text-signalling Effects on reading comprehension and information retention in expository texts. Teaching English In China, 2009, No. 5 , 98-100. Foreign Language Teaching and Research Press.

[15] Dickinson, D. (2002). Creating the further Perspectives on Educational Change. (Online) Available from Http://www.newhorizons.org/future/Creating-the-Future/crfut-entwistle.html12/07/ 08.

[16] Draper, S. W. (2009). Catalytic assessment: Understanding how MCQs and EVS can foster deep learner learning. British Journal of Education Technology, 40(2), 285-292.

[17] Entwistle, N.J. (1988). Styles of learning and Teaching. New York: David Fulton.

[18] Entwistle, N. J., \& Ramsden, P. (1983). Understanding student learning. London: Croom Helm.

[19] Entwistle, N., \& Tait, H. (1995). Approaches to studying and perceptions of the learning environment across disciplines. New directions for teaching and learning, 64, 93-103.

[20] Entwistle, N., McCune, V., \& Walker, P. (2001). Conceptions, styles, and approaches within higher education: analytical abstractions and everyday experience. In Sternberg and Zhang, Perspectives on cognitive, learning and thinking styles (pp. 103-136). NJ: Lawrence Erlbaum Associates.

[21] Farell, T. S. C. (2008). Planning Lesson for a Reading Class. Beijing: People's Education Press, p2.

[22] Goodman, K. S. (1967). Reading: a psycholinguistic guessing game. In Theoretical Models and Processes of Reading. H. Singer and R. Ruddell (Eds.). International Reading Association.

[23] Kember, D. and Leung, D. Y. P. (2006). Characterising a teaching and learning environment conductive to making demands on students while not making their workload excessive. Assessment \& Evaluation in Higher Education, Vol.31 (2)

[24] Lizzio, A, Wilson, K and Simons, R.(2002). University students' perception of on Press learning environment and academic outcomes: implications for theory and practice. Studies in Higher Education, 27 (1), p27 - 52

[25] Lave, J., \& Wegner, E. (1991). Situated learning: Legitimate peripheral participation. New York: Cambridge University Press.

[26] Marton, F., \& Säljö, R. (1997). Approaches to learning. In F. Marton, D. Hounsell, \& N. Entwistle (Eds.), The experience of learning. Implications for teaching and studying in higher education $\left(2^{\text {nd }} \mathrm{Ed}\right)$. Edinburgh: Scottish Academic Press. pp. 39-59

[27] Nisbet, J. \& Watt, J (1984). Case study. In J. Bell, T. Bush, A. Fox, J. Goodey and S. Goulding (eds) Conducting Small-scale Investigation in Educational Management. London: Harper and Raw, pp72-92.

[28] Nuttlull, C. (2002). Teaching Reading Skills in a Foreign Language. Shanghai: Shanghai Foreign Language Education Press, p16-17.

[29] Parahoo, K. (2006). Nursing Research Principle, Process and Issues. $2^{\text {nd }}$ edition, Palgrave McMillan, Hampshire.

[30] Qing xiou Bai, Chui Lin. (2008). New Century College English : An Integrated English Course ,Book IV. Shanghai: Shanghai Foreign Language Education Press.

[31] Ramsden, P. (2003). Learning to teach in higher education. 2ed. London and New York: RoutledgeFalmer.p41, p53.

[32] Sims, E. (2006). Deep Learning-1: A new way for schooling? International, pp1-8.

[33] Shu Baimei (1996). Teaching Intensive Reading within a Communicative Framework ,Teaching English In China,1996, No.3 . Foreign Language Teaching and Research Press.

[34] Tagg, J. (2003). The learning paradigm college. Boston: Anker.

[35] Tellis, W. (1997). Introduction to Case Study. The Qualitative Report. Vol 3(2),156-160.

[36] Trigwell, K., \& Prosser, M. (1991). Improving the quality of student learning: the influence of learning context and student approaches to learning on learning outcomes. Higher Education, 22, 251-266.

[37] Widdowson, H. G. (1979). Teaching language as communication. Oxford: Oxford University Press, pp.19.

[38] Widdowson, H. G. (1983). Learning purpose and, language use. Oxford: Oxford University Press.

[39] Walliman, N. (2001). Your Research Project: A step-by-step guide for the first time researcher. London: Saga Publication.

[40] Wellington, J. (2000). Educational Research: Contemporary Issues and Practical Approaches. London: Continuum.

[41] Xu Jinfen. (2006). The Theory and practice of Modern Foreign Language Teaching. Wuhan: Huazhong university press, p111-113. 
of Wolverhampton, Britain in 2011. She is currently an associate professor in the School of Foreign Languages, Yunnan Agricultural University, Kunming, China. Her research interests include English language teaching and English teaching methodology.

Jaswinder K. Dhillon was born in India and educated in the UK. She holds several degree and professional qualifications from different UK universities, including a PhD in Education from the University of Warwick and an MSc in TESP from the University of Aston. She is currently principal lecturer in learning and teaching in the School of Education, University of Wolverhampton, England and has taught TESOL and EFL to students from many different language and cultural backgrounds. Her current teaching is mainly on courses for MA students and her research interests include teaching and learning and effective partnership working amongst educational organisations. 